\title{
Experimentalismo fotoclubista: das fotoformas de geraldo de barros à decadência urbana de carlos navarro
}

Experimentalism photo club: from geraldo de barros photo forms until the urban decay of carlos navarro

Khetllen da Costa Tavares ${ }^{1}$

Luciane Viana Barros Páscoa²

ISSN: $2175-2346$ 


\section{Resumo}

A fotografia clubista tem como tradição o elogio da forma por meio do esmero técnico, contudo durante o período moderno ela passa por constantes tentativas de ressignificação dos fazeres fotográficos, a fim de torná-la mais abrangente. Visando o estudo da experimentação no fotoclubismo em Manaus, este artigo propõe realizar o estudo comparado entre as obras de dois fotógrafos: Carlos Navarro e Geraldo de Barros, articulando os possíveis diálogos estéticos entre eles, independente das temporalidades e territorialidades. A análise dos elementos visuais e das possibilidades interpretativas sugeridas nas imagens terão como base os estudos de Boris Kossoy, Costa e Silva, Fernandes Junior e Lima. Assim elegeu-se uma imagem da série Fotoformas de Geraldo de Barros (1923-1998) e outra imagem do ensaio Decadência Urbana de Carlos Navarro (1945-), ambas desenvolvidas durante parte do período clubista dos fotógrafos. Foram observadas as semelhanças e singularidades no que se refere à estética, técnica, controle, "erro", e recepção das obras. Por fim, verificou-se que os artistas estudados contribuíram cada um a seu modo, com a subversão do código fotográfico ao atravessarem os paradigmas dentro do contexto em que suas produções se desenvolveram.

Palavras-chave: Geraldo de Barros; Carlos Navarro; Fotoclubes; Experimentalismo; Modernidade.

\footnotetext{
${ }^{1}$ Mestranda do Programa de Pós-graduação em Letras e Artes da Universidade do Estado do Amazonas.

Amazonas - Brasil

khetllencosta@hotmail.com
}

\section{Abstract}

The clubber photography has a tradition praise of the way through the technical care, but during the modern period it goes through constant attempts to reframe the photographic doings in order to make it more comprehensive. Aiming at the trial study in photo clubs in Manaus, this article proposes to carry out a comparative study between the works of two photographers: Carlos Navarro and Geraldo de Barros, articulating the possible aesthetic dialogues between them, regardless of temporality and territoriality. The analysis of visual elements and interpretative possibilities suggested in the images will be based on the studies of Boris Kossoy, Costa e Silva, Junior Fernandes and Lima. Thus an image of photo forms series of Geraldo de Barros (1923-1998) and another image of the trial Urban Decay Carlos Navarro were elected (1945), both developed during part of clubber period of photographers. Similarities and singularities have been observed as regards the aesthetic, technical, control, "error", and reception of works. Finally, it was found that the artists studied each contributed in their own way, with the subversion of the photographic code when crossing the paradigms within the context in which their production was developed.

\section{Keywords: Geraldo de Barros; Carlos Navarro; photo clubs; experimentalism; Modernity.}

\footnotetext{
2 Professora da Universidade do Estado do Amazonas Amazonas - Brasil luciane.pascoa@gmail.com
} 


\section{INTRODUÇÃO}

O Fotoclubismo foi um movimento mundial e no Brasil desenvolveu-se no início do século XX em várias capitais e cidades do interior. Em Manaus este movimento é recente, contando com apenas três: Fotoclube Lentes da Amazônia (2011), Fotoclube Fotosíntese do Amazonas (2013) e Fotoclube Além do Olhar (2014). O primeiro credenciou-se em 2011 de acordo com a Confederação Brasileira de Fotografia (CONFOTO). Existe ainda o Fotoclube A Escrita da Luz fundado em 2005, mas sem registro na confederação.

A história do movimento fotoclubista no Brasil esteve associada ao desprendimento da fotografia ao caráter documental, possibilitando outras formas de pensar e produzir a obra fotográfica, aproximando-se das artes com intuito de homologar o caráter expressivo da linguagem. Ao verificar o estudo da fotografia no Brasil, observa-se a forte presença de fotógrafos que em algum momento da própria trajetória tiveram a produção advinda do âmbito clubista, caracterizando-o como lugar de reflexão fotográfica.

A fotografia clubista tem como tradição o elogio da forma por meio do esmero técnico. Durante o período moderno passou por constantes tentativas de ressignificação dos fazeres fotográficos, a fim de torná-la mais abrangente. Dentre as influências advindas da contemporaneidade, destaca-se a experimentação. Sendo assim, propõe-se observar o experimentalismo na fotografia contemporânea clubista em Manaus.

Ao visualizar a produção do Fotoclube Fotosíntese do Amazonas, notou-se a singularidade da poética do fotógrafo Carlos Navarro nesse âmbito, devido à desconstrução de algumas tradições estéticas clubistas observadas na série Decadência Urbana. Logo, mostrou-se oportuna a escolha do fotógrafo como objeto de estudo para a experimentação no fotoclubismo em Manaus. Para tanto, recorreu-se ao estudo de caso comparado com o artista Geraldo de Barros que atuou como fotógrafo no Foto Cine Clube Bandeirante na modernidade, pioneiro no experimentalismo fotográfico. Além disso, existem pesquisas desenvolvidas a respeito da produção de Barros, auxiliando o desenvolvimento deste estudo realizado com Navarro, fotógrafo com quase 50 anos de produção, vivendo 42 em Manaus, porém ainda inédito no ambiente acadêmico.

Sendo assim, propõe-se observar a experimentação na fotografia fotoclubista contemporânea em Manaus, por meio do estudo comparado entre as obras de Carlos Navarro e Geraldo de Barros, ao articular os possíveis discursos e diálogos estéticos, independente das temporalidades e territorialidades. Pretende-se identificar semelhanças e diferenças entre os fotógrafos e verificar a recepção do experimentalismo no cenário clubista em Manaus. Para tal fim, elegeu-se uma imagem da série Fotoformas de Barros e outra da série Decadência Urbana de Navarro, ambas desenvolvidas durante parte do período clubista dos autores.

Visando a compreensão desses aspectos, optou-se por analisar as imagens selecionadas através dos estudos de Boris Kossoy, os quais determinam que: "Três elementos são essenciais para a realização de uma fotografia: o assunto, o fotógrafo e 
a tecnologia." (KOSSOY, 2001, p.37), estes manifestos em um determinado tempo e espaço, com isso propiciando a investigação dos elementos visuais e das possibilidades interpretativas sugeridas nas imagens. Somando-se à metodologia desta pesquisa, utilizaram-se os teóricos: Heloise Costa e Renato da Silva, Heloisa Lima e Rubens Fernandes Junior que desenvolveram pesquisas sobre a fotografia moderna no Brasil associada ao fotoclubismo, estendendo-se à Geraldo de Barros.

Acredita-se que é possível estabelecer diálogos entre imagens independentes de seus conceitos, estes observados de acordo com olhar do pesquisador em apresentar a riqueza do tema estudado. A comunicação entre estas, acontece segundo Kossoy (2014, p.149) por: “[...] fatores formais, culturais, emocionais, estéticos, ideológicos ou de outra ordem; uma ligação que tem vida própria, autossuficiente, cujo circuito se fecha na medida em que alguns de nós as olhamos e intuímos uma alteração da ordem natural das coisas; [...]". Visando esses preceitos, efetuou-se a articulação entre a produção de Geraldo de Barros e Carlos Navarro, através da escolha das obras: Homenagem a Stravinsky (1949) de Barros e a Decadência Urbana (2012) de Navarro. A primeira reúne elementos da estética fotográfica tradicional, porém com a inserção do desenho na imagem; enquanto a segunda desconstrói parcialmente o caráter referencial, assim sugerindo semelhanças e singularidades entre eles.

Compreende-se que: "A imagem fotográfica vai além do que mostra em sua superfície. Naquilo que não tem explícito, o tema registrado tem sua explicação, seu porquê, sua história. Seu mistério se acha circunscrito, no espaço e no tempo, à própria imagem." (KOSSOY, 2014, p.62). Sendo assim, a fotografia possibilita conhecer o mundo além das representações, para isso, é preciso realizar um mergulho processual, através da interpretação de cada elemento da obra, estabelecendo as relações entre estes e o possível conceito do autor expresso na foto.

\section{A ESTÉTICA FOTOCLUBISTA MODERNA}

O esmero técnico é um dos aspectos recorrentes na produção fotoclubista, visando uma fotografia diferenciada daquela produzida pelos considerados amadores, buscando a auto afirmação por meio desta, consequentemente, restringindo o espaço para a experimentação fotográfica. A experiência pictorialista foi pioneira nesse processo a partir dos anos 1920, contudo a fotografia precisava corresponder esteticamente à pintura acadêmica, a fim de garanti-la o status de arte. A partir de 1940, as reflexões sobre os fazeres fotográficos avançaram, e as produções apresentaram outras formas de construção imagética, explorando as pontecialidades da câmera e os padrões clássicos de composição, porém a hibridização da fotografia com outras linguagens não era aceita pela maioria dos clubistas.

A fotografia moderna conquistou muitos adeptos clubistas, principalmente os mais jovens. Dessa maneira, era frequente nos trabalhos o uso de composições geométricas, elementos com um certo grau de abstração, mas não dissociados do referente. Um dos pioneiros a subverter esses padrões clubistas foi Geraldo de Barros, que questionou os limiares da liguagem fotográfica no modernismo, atráves de várias intervenções na imagem. "Nessa época, ainda não há nos trabalhos dos fotógrafos 
clubistas experiências que se aproximem das Fotoformas." (LIMA, 2006, p. 122), o que garantiu a Barros o caráter inovador das obras. O fotógrafo ingressou no Foto Cine Clube Bandeirante "em abril de 1949, já com uma experiência anterior em artes plásticas. Fez fotos de cenas montadas e fotografou objetos, enfatizando o ritmo de seus elementos constitutivos." (COSTA; SILVA, 2004, p.43). Também fez várias exposições de uma mesma chapa, recortes, desenhos, sobreposições realizadas no negativo e montagens fotográficas, entre outros procedimentos. Portanto, Barros começou do convencional, e ao avançar as pesquisas fotográficas, ele desenvolveu imagens sugestivas, em vez de representativas, convidando o espectador a criar suas próprias interpretações, ao propor novas leituras da fotografia. Tornou-se um visionário, ao impor sua singularidade processual no âmbito da produção clubista.

\subsection{Geraldo de Barros}

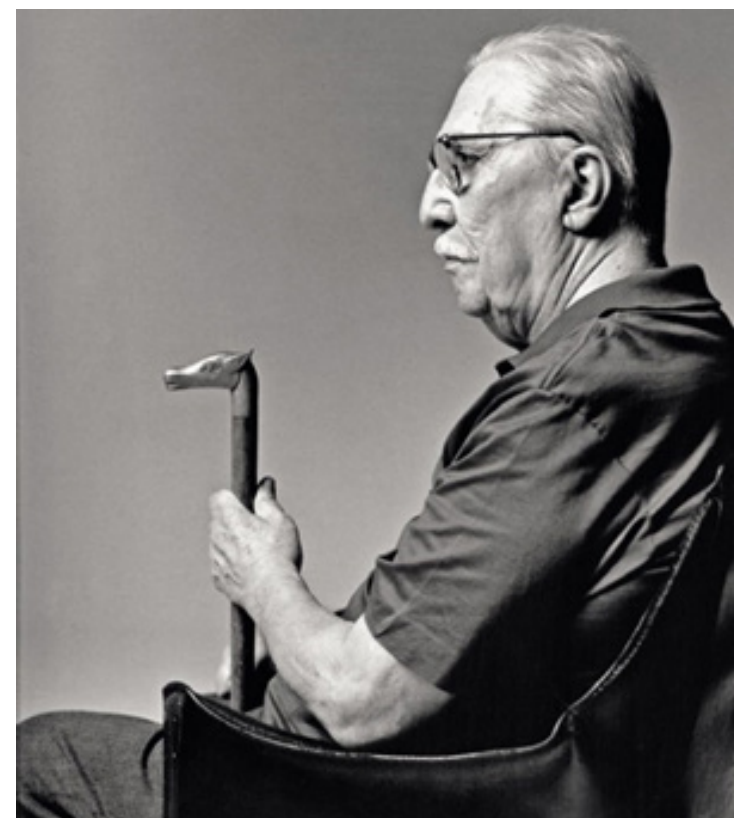

Fig 1. : WOLFESON, B. 1998. 1 fotografia. p\&b. In: FERNANDES, R. Jr; (Texto e organização). Sobras: Geraldo de Barros. São Paulo: Cosac Naify, 2006.

Geraldo de Barros (Fig.1) nasceu em 1923, na cidade de Xavantes interior de São Paulo, em 1946 estudou pintura e desenho com Clóvis Graciano, também se inscreveu na Associação Paulista de Belas Artes. Nesse mesmo ano conheceu Athaide de Barros, o qual the apresentou a fotografia. Em 1948 participou da criação do Grupo XV reunindo cerca de 15 artistas, adiante construiu um laboratório no ateliê do grupo, comprou uma máquina Rolleiflex em 1939, e começou a se aprofundar na fotografia. Um ano depois se associou ao Foto Cine Clube Bandeirante, do qual seria o mais novo entre os membros. Foi convidado a montar o laboratório de fotografia do Museu de Arte de São Paulo, inserindo a fotografia nas Belas Artes. No ano de 1950 realizou a exposição da série Fotoformas e com o sucesso do trabalho ganhou uma bolsa de estudos para estudar pintura e gravura em Paris em 1951. No ano seguinte voltou ao Brasil e participou da fundação do Grupo Ruptura, junto a outros artistas, dentre eles, Waldemar Cordeiro. Em 1956 participou da primeira Exposição Nacional de Arte Concreta e em 1960 expôs em Zurique. Abandonou o construtivismo geo- 
métrico em 1964, e adentrou na Pop Art repintando cartazes publicitários, propondo uma leitura crítica e subjetiva. Voltou à fotografia em 1975, retrabalhando as imagens da década de 1940 a 1950, consequentemente retornando ao geométrico, porém em 1980 ele radicalizou sua produção aplicando o processo industrial à pintura. (FAVRE in FERNANDES, 2006)

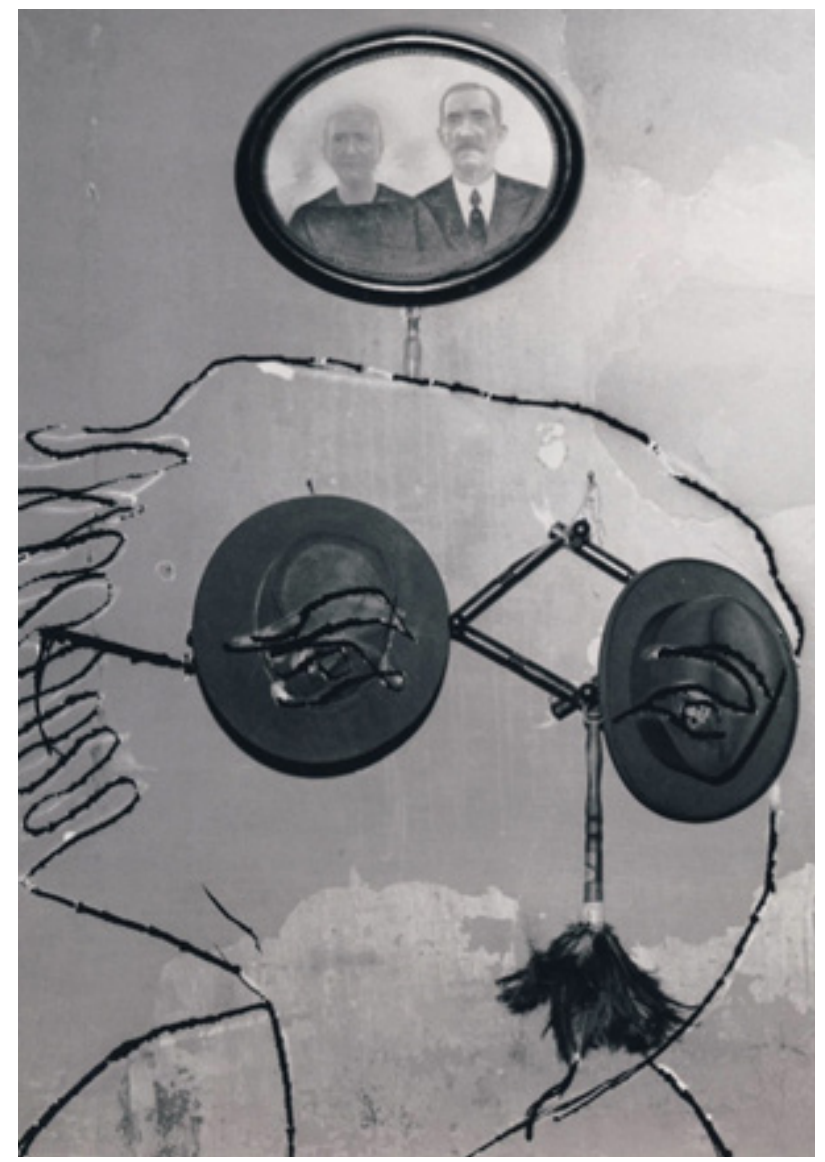

Fig. 2: BARROS, G. Homenagem a Stravinsky. Piracicaba, São Paulo, Brasil, 1949. Desenho sobre negativo com ponta-seca e nanquim. 1 fotografia, $p$ \& b. Altura: 1006 pixels. Largura: 700 pixels. 300 dpi. BIT CMKY. 51,2 KB. Formato JPG. Disponível em: < http://thephotographersgalleryblog.org.uk/2013/01/16/what-remains-isobel-whitelegg-on-geraldo-de-barros/gdb_fotoformasdrawing/ >. Acesso em: 19 maio. 2015.

Em Homenagem a Stravinsky (Fig 2.) visualiza-se na parte superior uma foto emoldurada em formato elíptico contendo a representação de um casal de idosos, composta da seguinte maneira: em primeiro plano a imagem da senhora idosa, característica observada por meio da tonalidade do cabelo, e as linhas de expressão de seu rosto, em segundo plano o personagem masculino, também aparentando uma faixa etária próxima da personagem anterior, vestindo terno e gravata, ambos registrados em close-up.

A composição do casal sugere elementos característicos do retrato pintado, o qual sobrevive em localidades afastadas dos grandes centros urbanos no interior do Brasil, carentes de estúdios fotográficos e dependendo da visita de vendedores intinerantes que oferecem a encomenda dos retratos, também são parte integrante da decoração dessas casas. Os temas recorrentes são: "[...] um casal e seus filhos, ou apenas o casal, um filho formado ou recém-casado, ou um ente falecido. A maioria das encomendas dos retratos se faz com base em um retrato de documento, uma foto 3x4 entregue ao vendedor [...]" (NAKAGAMA in SANTOS, 2012, p.15), assim como 
era comum à inspiração nos modos de vida e vestimentas dos artistas e personagens dos anos de 1930 a 1960, itens observados no quadro do casal estudado. Os retratos são feitos a partir de modelos preexistentes ou por meio da descrição fisionômica do retratado, outras encomendas visam a restauração ou recuperação de retratos deteriorados pelo tempo (Fig. 3).

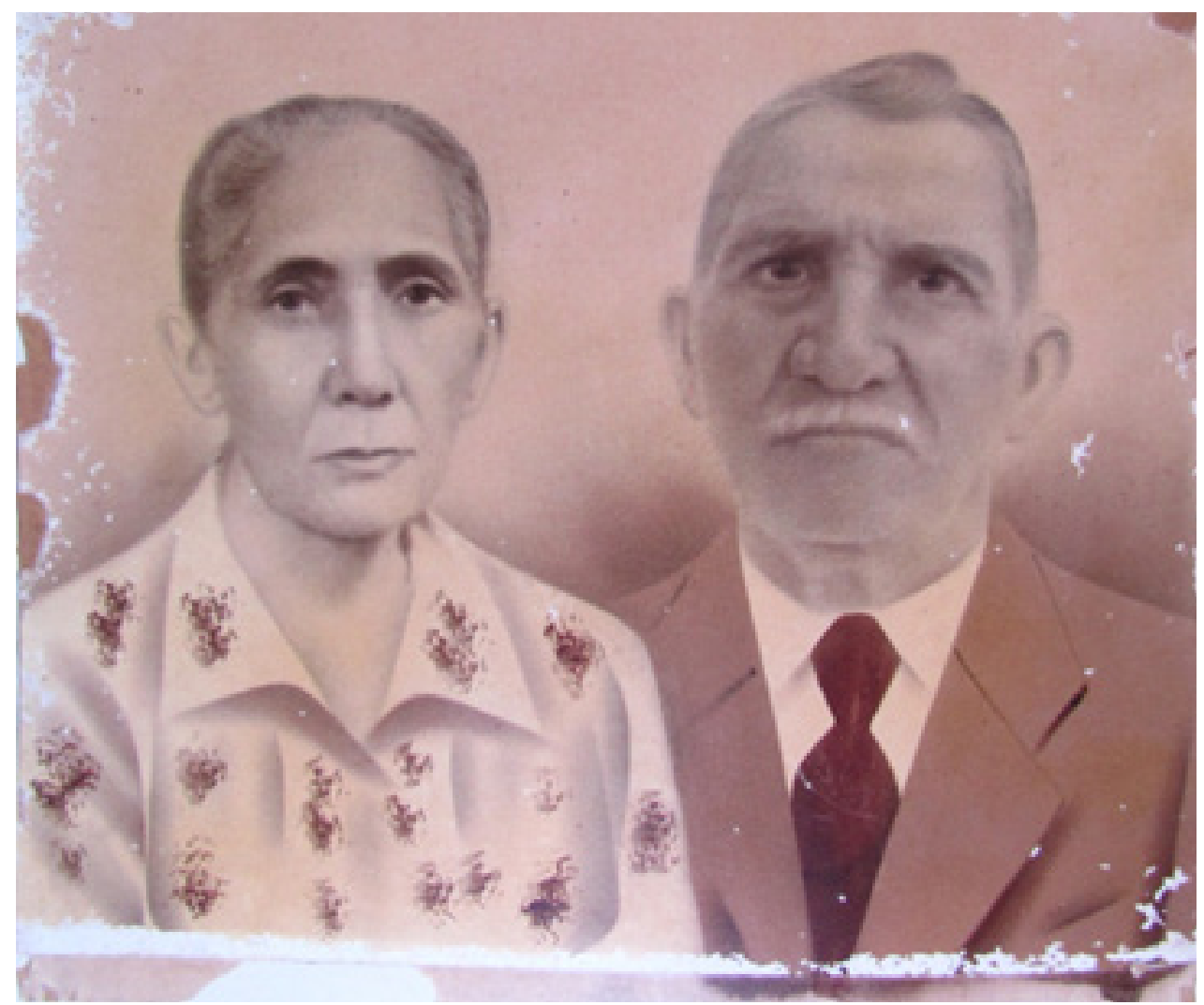

Fig 3. ÁUREO STUDIO. Zé Maria Pretinho, Anônimos, 1960. Fortaleza, Ceará, Brasil. 1 fotopintura, color. In: SANTOS, J. Interior profundo - Mestre Júlio Santos, fotopintura = The deep within - Mestre Júlio Santos, photo painting/ Júlio Santos - Fortaleza, CE: Tempo D'Imagem, 2012.

Porém a Fotopintura sofreu com o declínio da fotografia analógica e dos laboratórios no Brasil, devido ao fim da produção de diversos materiais utilizados no retoque das imagens. Em alguns lugares do nordeste do Brasil, ainda se mantém o costume de tê-los no ambiente familiar. Poucos laboratórios sobreviveram à massificação da câmera digital, no caso de Mestre Júlio Santos retratista bastante divulgado nacionalmente e no exterior, foi um dos que precisou adaptar-se ao processo digital, utilizando o Photoshop na construção das imagens. (NAKAGAMA in SANTOS, 2012)

A manipulação é um ponto comum à fotopintura e à produção de Geraldo de Barros, ambos utilizam a fotografia como meio. A fotopintura é realizada em etapas: primeiro faz-se a reprodução e ampliação da foto original em preto e branco, geralmente no formato $3 \times 4$, a seguir recorta-se o rosto e constrói o fundo, e por fim elaboram-se os detalhes do rosto e a inserção de adereços, de acordo com as recomendações solicitadas no momento da encomenda ( NAKAGAMA in SANTOS, 2012), 0 resultado pode ser observado abaixo (Fig. 4). Sendo assim, a fotopintura se apropria da fotografia como agente de memória, enquanto nas Fotoformas, ela é vista como uma ferramenta expressiva, logo ambas tratam a fotografia como um meio. 


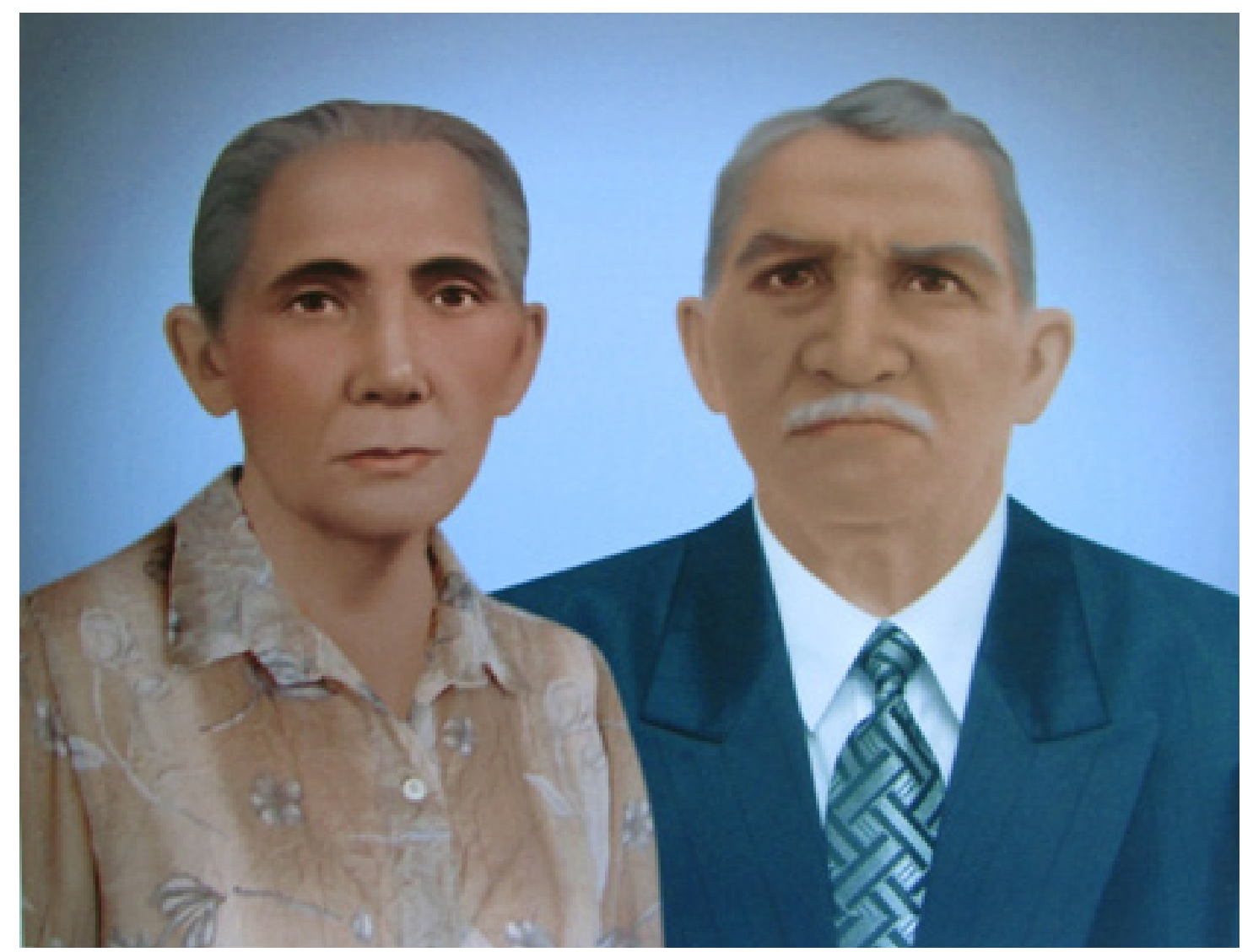

Fig 4. ÁUREO STUDIO. Zé Maria Pretinho, Anônimos. 1960. Fortaleza, Ceará, Brasil. 1 fotopintura colada em papelão, papel fotográfico de fibra, tinta a óleo, pigmentos minerais, retoque com esfuminho, e uso de moldes de acetato para golas e gravata. Color. In: SANTOS, J. Interior profundo - Mestre Júlio Santos, fotopintura = The deep within - Mestre Júlio Santos, photo painting/ Júlio Santos - Fortaleza, CE: Tempo D'Imagem, 2012.

Assim, sugere-se a associação entre a fotopintura construída por imagens advindas do mundo interior daqueles que perderam fragmentos da memória individual, e a construção da fotografia de Barros ao inserir uma imagem no interior de outra, relacionando diferentes elementos interpretativos, transcedendo as superfícies visíveis da representação, assim como a duplicidade entre a imagem pública de Stravinsky e a imagem privada do casal de idosos, fundidos na mesma cena.

Adiante, observa-se em Homenagem a Stravinsky que há uma figura ocupando grande parte do espaço representativo, em primeiro plano formada por linhas ora soltas, ora fragmentadas compondo a imagem de um homem em semiperfil, de caráter figurativo estilizado, o qual por meio do título, entende-se ser o músico modernista russo, Igor Stravinsky. Esta imagem se relaciona com os chapeús apoiados, um em cada extremidade da chapeleira de parede, e um espanador localizado próximo ao chápeu da extremidade direita, dispostos sobre uma parede corroída, talvez pela ação do tempo em sua estrutura, observadas nas manchas claras na pintura na parede.

O resultado final é a soma entre a linguagem fotográfica e o desenho, firmando um jogo de adivinhação das formas, uma fundida na outra, através da relação integrada de figura e fundo. O desenho que representa Stravinsky é a figura, e a cena capturada na foto o fundo, cada elemento se relaciona com o outro para comportar o todo, exemplo, olhos fundidos nos chapeús, quando juntos a chapeleira de parede 
formam a estrutura dos óculos, e o espanador assume a representação do bigode do homenageado. Nesse processo a imagem adquire um caráter lúdico através da estilização do desenho, atribuindo um aspecto humorístico ao retrato, contrapondo a representação acadêmica e a verossimilhança característica da fotografia.

O uso do desenho na composição de Barros estaria associado ao interesse que possuía com a produção de Paul Klee, Alexander Calder entre outros. Contudo, em 1946, Barros visitava em São Paulo a Escola Livre de Artes Plásticas, dirigida pelo psiquiatra Osório César, que realizava procedimentos da terapia ocupacional com pacientes internos no Hospital do Junqueri e outros, posteriormente observaram as semelhanças entre os desenhos de Geraldo de Barros e os desenhos de Raphael Domingues, interno do hospital e portador de esquizofrenia. Ambos apresentavam um caráter figurativo estilizado nas representações, coincidências na forma do traçado, aproximando-se em alguns momentos do desenho infantil (LIMA, 2006). Outro caso, seria a interferência através da raspagem no negativo, proprocionando o efeito visualizado, procedimento bastante ousado e inovador para a produção do Foto Cine Clube Bandeirante daquela época.

Ao observar um retrato de Stravinsky (Fig.5), notou-se que o artista explorou dois elementos marcantes da fisionomia do músico: os óculos representados pelos chapeús típicos do vestuário masculinos da época do registro, e o bigode na forma do espanador, objeto característico do ambiente doméstico, utilizado para remoção da poeira, podendo simbolizar a remoção da tradição feita pelo músico.

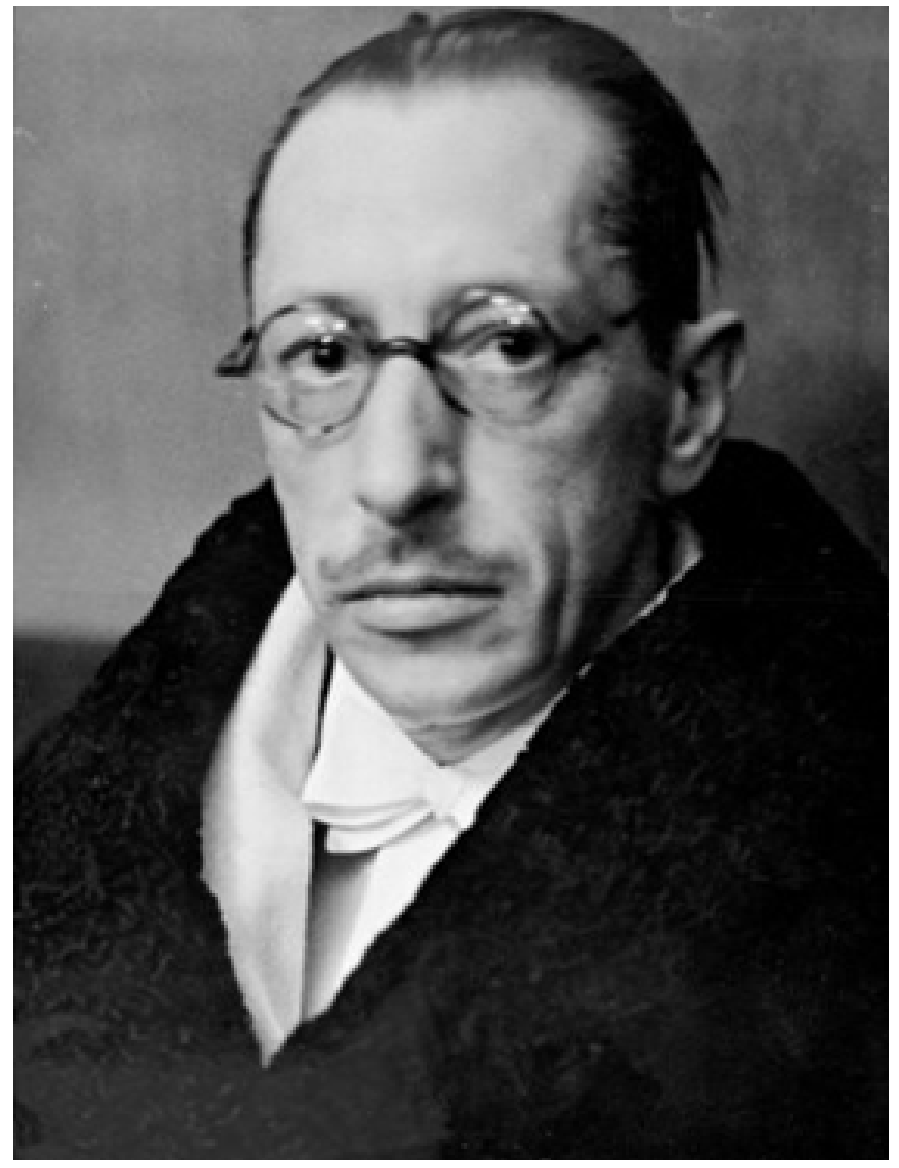

Fig 5. Autor desconhecido. [Sem título] . 1 fotografia, p \& b. Altura: 450 pixels. Largura: 338 pixels. 300 dpi. 289 KB. Fomato JPG. Disponível em: < http://www.providencesingers.org/Concerts06/Season11-12/Oct11Stravinsky.php>. Acesso em: 22 jun. 2015. 
Igor Fiodorovitch Stravinsky foi um dos maiores compositores do século XX, nasceu em Oraniembaum, na Rússia, em 17 de junho de 1882. Iniciou os estudos para advocacia, porém seu interesse por música foi maior. Em 1910, compôs a música para o balé O Pássaro de Fogo, encenado em Paris. Três anos depois, ele compôs a obra mais conhecida de sua carreira, $A$ sagração da primavera (1913), o que garantiu sua entrada para a história da música. No início da Segunda Grande Guerra Mundial, ele se mudou da França para os Estados Unidos, onde manteve o sucesso, por fim aos 80 anos, ele faleceu em 6 de abril de 1971, em Nova York (FOLHA ONLINE, 2015a). Stravinsky buscou inicialmente a música de origem russa, adiante passou para o neoclássico, valorizando as regras e princípios dos artistas europeus do século XVIII, contudo, fez várias experimentações na música, entre elas, a rítmica agressiva e as mudanças bruscas de compasso e harmonia, também na composição dos timbres, pois cada som era valorizado individualmente e tais elementos surpreenderam a plateia daquela época (FOLHA ONLINE, 2015b).

Em A Sagração da Primavera, o músico revoluciona características da música da época, pois utilizava dissonâncias, e o valor da percussão suplantava a própria melodia, algo que para aquele momento era inusitado, pois propunha uma nova estética na música. No processo de experimentação, o compositor criava com base na natureza folclórica, porém desconstruída (SANTANA, 2015c). Dessa maneira, pode-se estabelecer uma relação entre o modernismo de Stravinsky na música e o de Barros na fotografia, por meio da ousadia em desconstruir a estética, rompendo com os valores vigentes da época em que viveram, também por transitarem entre o popular e o acadêmico, por meio da associação da imagem do músico com uma cena da moradia interiorana de São Paulo.

Quanto à tecnologia analógica, em 1946, Barros se interessou pela fotografia, desconhecendo a história e com pouco domínio técnico, entretanto explorou o mecanismo do processo de revelação, como: sobreposição de negativos, solarização, estereoscopia, anaglifo, o que se refletiu na produção que apresenta uma imagem híbrida, ainda desmonstrou o interesse pelo jogo de luz e sombra, fissuras, asperezas, grafites (BARROS, G., 2006).

Geraldo de Barros começou a fotografar com uma câmera Rolleiflex, acompanhada do manual, em que constavam advertências sobre o que não fazer ao fotografar, porém "ele vai e risca, o manual falava não risque o negativo, não fotografe luz, ele ia e fotografava contraluz, não bata a mesma foto no mesmo fotograma, ele vai e aprende até controlar essa dupla exposição no mesmo clichê" (BARROS, F., 2014). Logo, percebe-se que o artista não se preocupava com padrões da fotografia vernacular, ao invés disso, priorizou a multiplicidade, ressignificação e construção da fotografia, o que o impulsionou a adentrar na abstração e geometrização do referente.

No que tange o espaço referencial, a imagem foi feita em Piracicaba, cidade do interior de São Paulo, logo, a foto apresenta elementos da cultura interiorana, carregando consigo artefatos da memória social e afetiva daquele lugar. $O$ registro da imagem é 1949, período em que o Brasil era governado por Eurico Gaspar Dutra (1946 a 1951), no cenário mundial acontecia a Guerra Fria entre Estados Unidos e União Soviética, enquanto no nacional acirravam-se os debates entre liberalismo e nacionalismo. O país acumulou reservas para investimento, posteriormente usou no 
cormécio internacional, possibilitando a compra de várias obras de arte a baixo custo, desencadeando a criação de três museus. Além disso os artistas se voltaram para os temas populares, visando o engajamento social através das artes. Sendo assim, a figuração era um elemento chave nesse processo, aspecto que evidencia a ousadia de Barros no uso da abstração ( MEIRA, 2006).

\section{EXPERIMENTAÇÃO NA FOTOGRAFIA CONTEMPORÂNEA}

A fotografia contemporânea transita em vários campos, dialogando com outras linguagens, assumindo diversos suportes, entre fronteiras pouco delimitadas, apresentando: " "[...] linhas ambíguas, da abstração, do analógico ao digital, do artesanal ao mecânico, simultaneamente documental e processual. Apesar dos cânones vigentes ao longo da História da Fotografia, nunca existiu apenas um tipo de fotografia" (DIEGUES; ORTEGAS, 2013, p.9). Logo, no contexto atual, se reafirma uma imagem de natureza múltipla, que questiona e reinterpreta a realidade proposta nas fotografias.

Fotografia construída é outro termo denominado para a fotografia contemporânea, caracterizada quando o fotógrafo assume a posição de construtor, pois através das ferramentas disponíveis, ele reelabora a realidade no âmbito da cultura técnica, se opondo ao papel anterior de caçador. Neste último, o fotógrafo se apropriava daquilo que a natureza oferecia, proposta bastante difundida com a noção de instante decisivo por Henri Cartier Bresson. (ENTLER, 2011)

No percurso de experimentações na estética fotográfica nos anos 1940, menciona-se aqueles que iniciaram tal processo: José Oiticica Filho, com as fotografias de estética abstrata e geométrico-construtiva; de Geraldo de Barros com as Fotoformas; também as fotomontagens de Athos Bulcão e do escritor Jorge de Lima (COCCHIARALE in GURAN, 2010). Estes que propuseram novas formas de fazer fotográfico, posteriormente difundido entre outros fotógrafos e artistas.

Ao final da década de 1960, "o artista brasileiro desse momento, preocupado em registrar situações efêmeras por eles criadas, teve de lançar mão dos meios tecnológicos que the eram acessíveis" (COCCHIARALE in GURAN, 2010, p.22), logo, se apropriando das novas tecnologias para a produção artística, pela necessidade de experimentação. Contudo, nesse período, a fotografia ainda não era um meio aceitável e disponível para os artistas visuais, por conta dos questionamentos relacionados à mimese da imagem produzida pela câmera, à expressividade, e o controle do autor sobre a tecnologia.

Portanto, o processo de experimentação da fotografia e sua inserção na arte contemporânea brasileira tem sua origem atrelada à produção fotoclubista, representada por Geraldo de Barros e José Oiticica Filho. Visto que, "é absolutamente impensável, você olhar para a fotografia contemporânea, sem perceber que há em momentos anteriores, uma construção de grandeza estética, da importância do Foto Clube Bandeirante. [...]" (FERNANDES, 2014). Assim, ressaltando a importância dos experimentos iniciados dentro do fotoclube, que possibilitaram o espaço para reflexão do fazer fotográfico, mesmo diante da forte resistência por parte de alguns 
membros, levando a fotografia a outros patamares, o que propiciou sua entrada em galerias e bienais.

Diante disso, propõe-se observar como a experimentação acontece no fotoclubismo contemporâneo em Manaus por meio da análise da imagem e a articulação entre as poéticas de Geraldo de Barros e Carlos Navarro, este que se singulariza no âmbito clubista, devido à desconstrução parcial da realidade figurativa, expressa em perspectivas inusitadas e matizes vibrantes.

\subsection{Carlos Navarro}

Carlos Alberto Navarro Infante (Fig.6) nasceu em Caracas (Venezuela) em 1945, iniciou como fotógrafo amador em Barcelona (Espanha) no ano de 1966, onde a sua curiosidade foi despertada em torno das técnicas de revelação laboratorial em preto e branco, consequentemente montando o próprio laboratório de forma artesanal. Este fato o levou a procurar emprego de ajudante de laboratório e tendo acesso às etapas de revelação a cores, posteriormente assumiu o cargo de gerente de laboratório. Em 1972, a partir de um anúncio de jornal em que oferecia uma vaga de técnico de laboratório a cores, disposto a formar, instalar e produzir a serviços da empresa Sonora, com sede em Manaus (Brasil), com o aceite em 1973, iniciou a carreira de diretor gerente operacional técnico eletrônico e instrutor de recursos humanos para a fotografia. Assim tornou-se pioneiro no norte do Brasil em fotografia a cores. Em 1982, ele optou por sair da empresa iniciando a carreira de fotógrafo autônomo na área de processamento fotográfico, registro de eventos e instrutor técnico, o que o levou ao desenvolvimento da fotografia artística, proporcionando a realização de várias exposições de caráter local e nacional, além dos prêmios e homenagens na área da fotografia. Em 2005, adentrou na fotografia digital, iniciando um novo estágio em sua produção fotográfica.

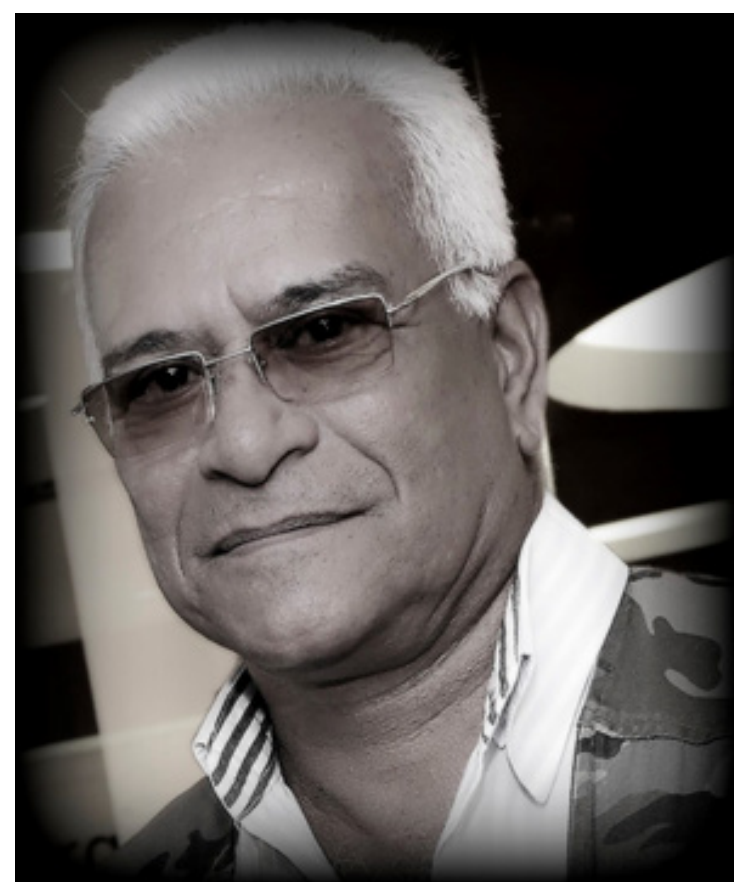

Fig 6. Autor desconhecido. [Sem Título]. 2015. 1 fotografia, color. Altura: 1165 pixels. Largura: 964 pixels. 300 dpi. 129 KB. Fomato JPG. 1 CD-ROM. Acervo do Artista. 
Navarro se interessou pela fotografia, ainda na juventude, quando participou de movimentos de contestação política em seu país de origem, nos anos de 1960, período de grande tensão devido o domínio dos governos ditatoriais vivenciados nos países da América do Sul. Naquele cenário a fotografia surgiu para ele como ferramenta na luta por igualdade de direitos sociais e civis. Relata-se que:

[...] fiz parte da classe estudantil, e ingressei na Juventude Comunista em 1963 até 1966, fiz parte da Guerrilha Urbana em Caracas e depois da Guerrilha Rural das Montanhas na Venezuela até 1965, onde fui preso na cadeia política. Em 1966, fui exilado na Europa e decidi ficar na cidade de Barcelona (Espanha) como exilado político. [...] Na época das guerrilhas rurais, tivemos a visita de vários jornalistas para documentar a vida dos guerrilheiros, e isso me chamou a atenção, pela fotografia [...] (NAVARRO, 2015a)

Sendo assim, sugere-se que a relação do fotógrafo com o documental esteve intrínseca desde o começo de sua produção, gerada a partir do contado com os fotojornalistas, além disso, identifica-se que a contestação é um fator presente em vários projetos realizados por ele, por meios destes, expõe o silêncio das pessoas que vivem no exílio social do cotidiano, porém alcançam visualidade através das lentes do fotógrafo, por meio de temas referentes ao resgate da memória, exaltando ritos e costumes da sociedade amazônica, preservando elementos referentes ao patrimônio material e imaterial do homem sul-americano.

O fotógrafo contribui com a fotografia produzida em Manaus, por meio de palestras em eventos destinados ao público local, relacionado ao fazer fotográfico, nos quais tem a oportunidade de relatar sua experiência e experimentações nos ensaios que produz. Também atuou como professor em vários segmentos, entre eles, ministrou aulas em projetos do Governo do Estado do Amazonas, voltado para menores de áreas periféricas urbanas da capital. Envolveu-se ativamente com a formação de grupos de fotografia, e fotoclubes locais, entre eles o Fotoclube A escrita da Luz e o Fotoclube Fotosíntese do Amazonas, cooperando com as iniciativas de difusão do fazer fotográfico na sociedade amazonense.

Atualmente continua a desenvolver projetos fotográficos que nunca fecham, sobre questões que evocam a memória como agente de resistência, priorizando o registro do patrimônio material e imaterial, através de ritos e costumes desenvolvidos por uma determinada parcela da sociedade, que mantém fazeres propícios ao desaparecimento nas futuras gerações. Também, percebe-se que a produção não se restringe ao documental, mas estende-se ao campo processual, vista na desconstrução estética das cenas capturadas, independente da objetividade da câmera, referente à cópia da realidade. Mostra uma visão ousada de produzir fotografia, diante da própria trajetória ao longo de quase 50 anos de produção, e principalmente quanto à recepção desses ensaios no ambiente fotoclubista. 


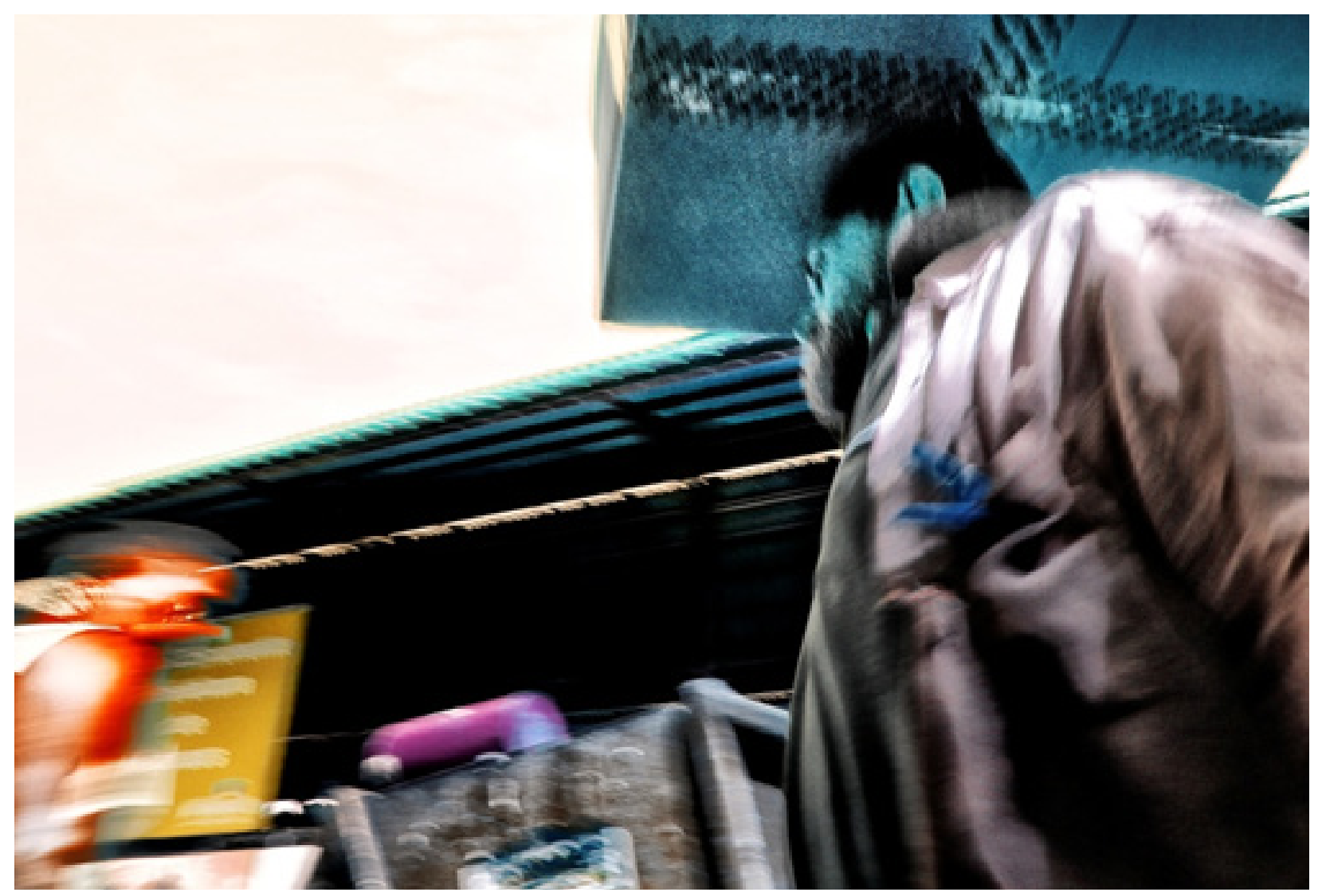

Fig. 7: NAVARRO, C . Decandêcia Urbana. 2012. 1 fotografia, color. Altura: 2592 pixels. Largura: 3888 pixels. 300 dpi. 289 KB. Fomato JPG. 1 CD-ROM .Coleção do Artista.

A imagem selecionada integra o ensaio intitulado: Decadência Urbana (Fig.7), no qual o fotógrafo registrou o patrimônio arquitetônico amazonense, concentrando grande parte da produção no centro histórico de Manaus, denunciando o descaso e abandono das construções por parte de órgãos governamentais. Propõe a fotografia como meio de resistência e preservação de memória individual e coletiva, aspectos dependentes do acúmulo das experiências culturais de cada espectador.

O uso da fotografia para este fim é recorrente desde sua invenção, pois através dela é possível cristalizar um fragmento de espaço e tempo da realidade. Nesse mecanismo, a memória coletiva é construída através da documentação fotográfica de "[...] monumentos, arquitetura, de suas vistas e paisagens urbanas, rurais e naturais, de suas realizações materiais, de sua gente, de seus conflitos e de suas misérias." (KOSSOY, 2014, p.132), alguns desses aspectos são registrados no ensaio, mostrando o engajamento do fotógrafo com o lugar e povo amazonense. Apesar da temática a princípio sugerir um caráter documental, o fotógrafo articula o discurso de maneira processual, no qual reinterpreta o fazer fotográfico dentro da perspectiva documental.

O fotógrafo relatou em entrevista presencial que desenvolve o ensaio estudado há bastante tempo, contudo nos últimos 5 a 6 anos, ele tem modificado o formato, por meio do uso da cor, evidenciado através da saturação de matiz, retirando-a do campo realístico. Pretende levar à população local a conscientização da importância do patrimônio histórico atrelado à memória da cidade. Ao questioná-lo sobre o envolvimento com o tema do ensaio, ele expôs que participou de um projeto do Governo do Estado do Amazonas intitulado La Belle Époque que visava recuperar vários 
patrimônios arquitetônicos. O artista relata que:

[...] Nessa época comecei a acompanhar todos os trabalhos, e tive a oportunidade de documentar toda a recuperação dessas casas, porque deu forças e ajudou a montar uma grande produção de fotografia que eu tenho, então participei do concurso com essa fotografia, ganhei, e hoje procuro trabalhar nesse projeto Decadência Urbana, como meio de sensibilizar as pessoas ou alguma área do governo que se interesse por recuperar esses prédios, esses patrimônios da cultura do Estado. [...] (NAVARRO, 2015b.)

A partir disso, percebe-se que o interesse pelo tema é recorrente em sua produção, que reúne imagens de vários projetos de documentação do patrimônio deste estado. Entre eles está o restauro do Teatro Amazonas realizado entre os anos de 1986 a 1990, do qual o fotógrafo mantém um grande número de negativos do projeto, reunindo um riquíssimo acervo da memória imagética do Amazonas.

Observou-se na imagem selecionada o teor figurativo, porém o caráter mimético intrínseco a fotografia, não se registra na totalidade do quadro, aproximando-se da abstração. O efeito é percebido por meio do desfocado, devido a pouca nitidez dos elementos representados, expresso pelo dinamismo alcançado com a baixa velocidade do obturador da câmera, mecanismo que age como uma "cortina", controlando o tempo de exposição para inscrição da imagem no sensor óptico ou no filme. Assim, o tema apresenta-se de forma sugestiva, na qual a identidade dos personagens não se inscreve em exatidão, sugerindo uma possível presença não revelada, de quem ou o que esteve ali, como aparições que desvanecem no espaço representativo.

Uso de diagonal na composição evidencia o dinamismo da imagem, porém a tensão visual é distribuída na cena, por meio do formato na variação de tamanho e tom, no qual o elemento em primeiro plano é de tamanho maior, e o que está em segundo plano menor, equilibrados visualmente através da cor, pois o maior é composto por tons de ocres e azuis, ou seja, cores frias, enquanto no elemento menor predomina os tons avermelhados, e pontos brancos, consequentemente, atraindo o olhar do espectador, permitindo-o percorrer por toda a cena registrada. Tal técnica é denominada de equilíbrio dinâmico "pode ser feito colocando o item com menor atração perto de um local importante dentro do quadro (os focos ativos dos centros de interesse) ou próximo às margens do quadro." (PRÄKEL, 2013, p.52) aspecto expresso na composição. Além disso, a cor foi utilizada fora do contexto representativo, evocando outras leituras.

Verifica-se o enquadramento contra-plongée, em que o fotógrafo posiciona a câmera voltada para cima, abaixo do nível dos olhos, apresentando uma visão inusitada do tema. Esse fator sugere a exaltação do tema representado, pois o elemento humano em primeiro plano, possivelmente um trabalhador carregando na cabeça um objeto geométrico, estende-se para além do espaço representativo, ressaltando sua importância visual e interpretativa na leitura da imagem. Também, percebe-se uma estética que desconstrói a realidade transformando-a em ambiente ficcional pictórico, através do referente e do uso da cor, explorando outras formas de apresentar um determinado tema de maneira inusitada.

Na trajetória de Carlos Navarro de quase meio século de produção, observou-se a impressionante reinvenção do fotógrafo, pois conseguiu transitar do sistema ana- 
lógico para o digital, processo que muitos fotógrafos de base fílmica, não conseguiram realizar. Sabe-se que o ato de se reinventar, não é um caminho simples, dito isto, a relação de Navarro com o computador começou no ambiente familiar, por meio do contato com os netos, que se intensificou quando ministrou aulas no projeto Jovem Cidadão oferecido pelo Governo do Estado do Amazonas. Neste projeto, Navarro ensinava a fotografia digital para adolescentes de áreas periféricas da cidade de Manaus. Durante o processo de ensino, Carlos Navarro teve maior contato com público jovem, que possui mais desenvoltura no uso do computador, estabelecendo-se a reciprocidade entre o fotógrafo e os alunos no processo de aprendizagem, enquanto o professor ensinava a fotografia aos aprendizes, eles ensinavam o uso da tecnologia. A partir disso, a desenvoltura com a ferramenta ampliou-se, possibilitando a trabalhar com programas de edição de imagem.

A imagem analisada provém da câmera digital, e a experimentação está associada ao uso de programas de edição, os quais o fotógrafo utiliza para desconstrução do referente, também explora o uso de filtros que são posicionados na objetiva da câmera, a fim de possibilitar maior controle por parte do autor com a imagem produzida. Vale ressaltar que apesar da desconstrução percebe-se a utilização de alguns padrões tradicionais de composição na fotografia, como o contraste do primeiro plano com o fundo.

O espaço representativo foi estruturado em três planos, o personagem em primeiro plano que se expande para fora do campo representativo, o segundo também, e entre os planos não se nota grande profundidade de campo. Por se tratar de uma imagem desprendida do caráter referencial, o tempo analisado foi o representativo, aquele do momento da tomada, o qual foi inscrito no quadro por meio da sugestão de movimentos, através do dinamismo visual presente na cena. Portanto, as reflexões não se estenderam ao aspecto cronológico contudo a foto foi feita em 2012, período posterior ao restauro feito em alguns prédios históricos ao longo dos anos 2000. Além disso, os ensaios de Navarro nunca são fechados, pois o fotógrafo está sempre os ampliando com a produção de novas imagens.

Porém, o descaso por parte de intuições governamentais relacionadas à preservação de patrimônio arquitetônico ainda é grande, principalmente com construções localizadas em ruas menos frequentadas, dessa forma, existe a constante tentativa de ampliar a conscientização dos manauaras em torno da preservação da sua história e memória nesses espaços.

\section{DIÁLOGO: SEMELHANÇAS E SINGULARIDADES}

A partir dos aspectos expostos, observou-se que estes fotógrafos possuem semelhanças e singularidades, a primeira se manifesta por meio do controle do autor na construção da imagem, somando-se a desconstrução da estética vigente de acordo com o período que pertencem, e a recepção da produção fotográfica em ambiente fotoclubista; quanto às singularidades, estas residem na maneira como cada um compreende o "erro" no fazer fotográfico, e o uso da técnica laboratorial na criação 
da obra.

Barros e Navarro desconstruíram a estética vigente, dos períodos pertencentes, o primeiro ampliou as possibilidades de construção fotográfica, influenciando gerações posteriores de artistas, quanto ao segundo, à singularidade do trabalho está especificamente na experimentação em ambiente clubista, pois a fotografia contemporânea está atrelada à multiplicidade de linguagens e suportes fundidos na imagem, os quais não foram observados na produção de Navarro.

Outro aspecto comum a ambos é autoria da imagem. Geraldo de Barros afirmava em 1951 que: "se eu me aproprio do negativo e faço algumas interferências nesse negativo, essa fotografia passa a ser minha, não de quem produziu o negativo." (FERNANDES JUNIOR, 2014). Questão bastante pertinente e atemporal, pois autoria, manipulação, apropriação da imagem são recorrentes nos debates entre artistas contemporâneos, e as fronteiras se estreitaram ainda mais com o uso da internet. Dentro dessa perspectiva, Navarro questiona a autoria da imagem na fotografia digital, acreditando que o uso em excesso de softwares de edição compromete a autoria total da imagem por parte do fotógrafo. Em entrevista presencial o fotógrafo expôs que:

[...] venho de uma época do analógico, onde nós, fotógrafos éramos proprietários do início ao fim de uma imagem que fotografávamos. Fazíamos uma composição e fotografávamos, revelávamos o filme, ampliávamos a cópia, fazíamos a edição, nós mesmos. Então é um trabalho próprio de você, você fazia todo aquele trabalho sem interferência de terceiros, como hoje que tem os programas de edição de imagem, como Photoshop, Ligthroom, outros programas onde engenheiros produzem esses programas e onde o fotógrafo tem a oportunidade de mexer, melhorar, modificar essa imagem, eu parto desse princípio que você não é cem por cento, autor dessa imagem. [...] (NAVARRO, 2015b.)

Através do depoimento do fotógrafo, observa-se os resquícios do pensamento, que autenticidade pressupõe controle sobre todo o processo da construção fotográfica, principalmente o manual, como o pintor que usa o pincel. Supõe-se que essa necessidade vem da forma de compreensão sobre a expressividade do autor, mensurada através da interferência manual, responsável por expor a singularidade do fotógrafo, afirmando seu estilo ao minimizar a objetividade da câmera.

A produção fotográfica de ambos percorreu os ambientes fotoclubistas, porém foram recepcionadas diferentemente. As experimentações nas obras de Geraldo de Barros, não eram consideradas como resultado fotográfico para os membros do Foto Cine Clube Bandeirante, devido ao inserção de outras linguagens na fotografia, e por questionar o lugar-comum em que o debate fotoclubista se encontrava. Barros declarou em um seminário interno do Bandeirante que: "Todo artista deve ser completamente livre, tendo compromisso apenas consigo mesmo." ( COSTA; SILVA, 2004, p.44), mostrando que o fotógrafo não se melindrava diante dos clubista, avançando com seus experimentos.

Geraldo de Barros era visto como um "atrapalhador" principalmente por Eduardo Salvatore, diretor do Foto Cine Clube Bandeirante que não aceitava a visão de Barros sobre a fotografia (BARROS, F., 2014). Relata-se que:

[...] ele fazia muita experiência, que ele evidentemente não sabia se ia dar certo, e muito sofisticadas as experiências, e só ia ver se deu certo, quando ele revelasse o 
filme, e ele revelava no Foto Cine Clube, saía do laboratório e gritava deu certo, consegui, e isso era horrível de se fazer, tinha uma lei de que um fotógrafo tinha que ter certeza do que ele fotografou, e que não existia falar uma coisa dessa. [...] (BARROS. F. 2014.)

Assim é possível verificar a preocupação com a precisão técnica que o clubista devia apresentar, que no processo criativo de Geraldo de Barros era compreendida como uma possibilidade criativa e expressiva. Outro motivo para rejeição por parte dos clubistas era "porque ele dessacralizava a matriz, porque para o fotoclubismo a matriz era a essência do resultado da fotografia. E para o Geraldo, a matriz era uma parte do processo que ele buscava na imagem fotográfica" (FERNANDES JR, 2014). Dessa maneira, observa-se que era na matriz que a fotografia dele saiu do lugar comum. O próprio Geraldo de Barros em entrevista concedida a Paulo Herkenhoff em 19 de abril de 1988, declarou que:

[...] Tive muitas brigas no Bandeirante, pois minhas ideias, minha visão da arte da fotografia, divergiam das dos fotógrafos que frequentavam o clube. Eles tinham uma visão acadêmica da fotografia, e eu me comportava como um curioso, buscando sempre soluções não convencionais para minhas fotos. [...] todos no Bandeirante me marginalizavam e me tinham como "louco".[...]. (HERKENHOFF 1988 apud LIMA, 2006, p.114)

A partir disso, observa-se a visão pejorativa em torno da produção do fotógrafo, e o conservadorismo extremista por parte do clube, tais aspectos podem ter contribuído para a saída de Barros na década de 1950, quando adentrou no movimento concretista paulistano abandonando a fotografia.

$\mathrm{Na}$ atualidade, o contexto da fotografia contemporanea é bastante diferente daquele vivido por Geraldo de Barros, pois a CONFOTO, orgão responsável por gerir os fotoclubes nacionais garante a liberdade criativa dos clubista na produção fotógrafica, inclusive adotando outros critérios avaliativos nas premiações dos eventos realizados por ela. Como exemplo, no regulamento da XXVIII Bienal de Arte Fotográfica Brasileira em Preto e Branco, realizada em agosto de 2014, pela primeira vez sediada em Manaus e organizada pelo Fotoclube Fotosíntese do Amazonas destinada aos clubistas, o item 4 do regulamento determinava que: "As obras fotográficas não estarão sujeitas a qualquer tipo de critério, tema, assunto ou técnica adotada, sendo garantida ao autor a mais ampla liberdade de criação nos limites das determinações previstas neste regulamento;" (CONFOTO, 2015a).

Complementa dizendo que: "os fotoclubistas não terão nenhuma restrição ao uso de qualquer forma para produzir sua obra final, podendo editar livremente, usando quaisquer ferramentas analógicas e digitais, Photoshop ou outros programas de edição de imagens, para fazer recorte, preparação de cenas, HDR, filtros, solarização, mudança de cor, contraste, brilho, efeitos especiais, adição ou eliminação de elementos, sobrepor imagens, redimensionamento, etc." (CONFOTO, 2015b). Portanto, percebe-se o reflexo da contemporaneidade na produção clubista, iniciados com Geraldo de Barros, respeitando as multiplicidades criativas e pluralidades dos membros.

Contudo, ao verificar os catálogos gerados nos últimos cinco anos com as fotos premiadas nas Bienais, identificou-se que as imagens premiadas não apresentam a desconstrução dos cânones, ou demonstram algum hibridismo. Pelo contrário, estas 
ainda preservam elementos da fotografia tradicional, como pode ser visualizado na fotografia (Fig.8) vencedora da XXVII Bienal de Arte Fotográfica Brasileira em Preto e Branco.

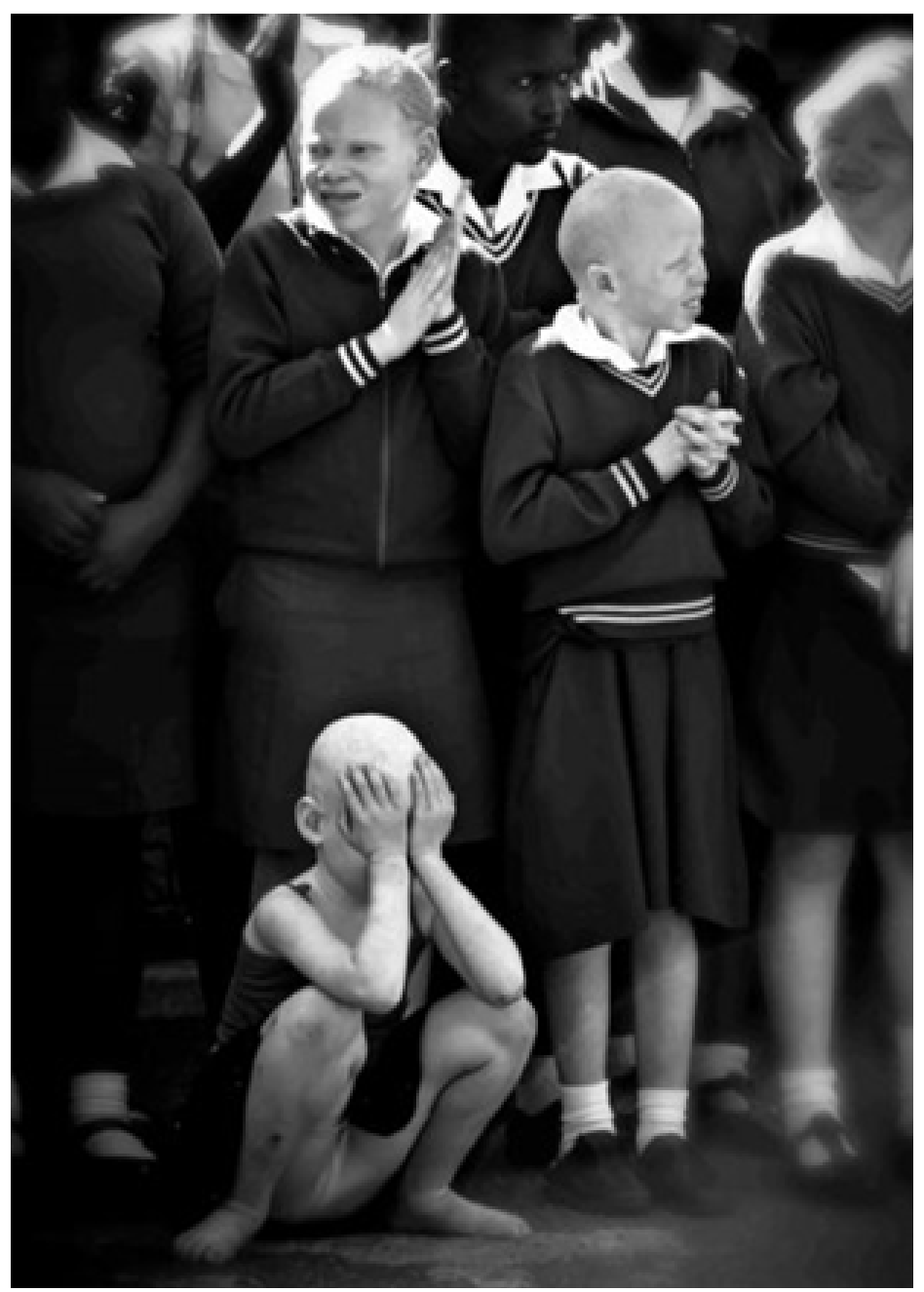

Fig. 8: HERRERA, P. M. Negro Branco. 1 fotografia, p \& b. Altura: 450 pixels. Largura: 338 pixels. 300 dpi. 289 KB. Fomato JPG. Disponível em: < http://confoto.art.br/bienal/index.php/inicio/category/1-classificacao-por-autor>. Acesso em: 05 jul. 2015.

A imagem apesar de apresentar um tema inusitado ao registrar os albinos, mantém o caráter referencial, a execução de acordo com padrões da fotografia tradicional, também não apresenta interferência de outras linguagens, preservando a tradição clubista do fazer fotográfico. Entretanto, Navarro não enfrenta resistência ferrenha por parte dos colegas clubistas quanto à recepção de suas obras, ao contrário, ele recebe a estima e admiração em vista da sua trajetória.

Outro aspecto inusitado na produção destes fotógrafos está em como consideram o "erro" no processo criativo. Na contemporaneidade, o "erro" está implícito aos fazeres, integrando parte da consciência, quebrando paradigmas que estiveram presentes nos movimentos de vanguarda, a fim de questionar os códigos vigentes de cada época. Para Fontcuberta (2010, p. 75) "[...] os resultados errôneos (aqueles que se desviam do código) são quase sempre ocasionados por um uso errôneo do aparelho (desvio de seu programa), a margem de manipulação tem que ser reduzida ao máximo". Tal aspecto foi explorado de maneira singular por Barros e Navarro, pois ambos desconstruíram o código, como também subverteram o equipamento, o que 
os possibilitou avançar na desconstrução da imagem fotográfica.

Geraldo de Barros compreendia o "erro" como uma possibilidade de criação, enquanto Navarro acredita ser uma falha, porém é importante frisar, que o impacto da transição do analógico para o digital influenciou a reinterpretação do fazer fotográfico, pois possibilitou a realização de experimentações que não aconteciam no sistema analógico. O próprio fotógrafo reconhece que o avançar da carreira o trouxe a maturidade, permitindo-o ousar, explorar o acaso e "o erro" como oportunidade de criação. Essa característica singulariza a produção de Navarro, pois comparado à produção de outros fotógrafos clubistas locais, ele propõe imagens transgressoras a algumas tradições do fotoclubismo.

Também, diferenciam-se na forma como exploram o uso da técnica laboratorial na criação da obra. Certa vez, Geraldo de Barros declarou que: " Me preocupei em conhecer a técnica apenas o suficiente para me expressar, sem me deixar levar por excessivos virtuosismos.[...]"(BARROS, G., 2006). Portanto utilizando-a como um meio para a expressão artística, inserindo outros procedimento na contrução da imagem, principalmente, durante o processo de revelação, pois é no laboratório que acontece os desdobramentos, a interrelação das linguagens, exemplo, o desenho, a colagem, a fotografia sem câmera, no caso, dos fotogramas.

Ao contrário de Navarro (2015b) que relata: “Eu me preocupo muito com a técnica, então quando eu produzo uma imagem, sou muito consciente do que estou produzindo, antes da captura já me preocupo, com a imagem boa, na edição também faço a mesma coisa, então pra mim a fotografia tem que estar boa. [...]". Dessa forma, observam-se os resquícios do ofício de laboratorista desenvolvido por anos pelo fotógrafo, quando era responsável pelo o controle de qualidade das imagens em consonância com a visão clubista, que Barros subverteu em seu processo criativo. Além disso, Carlos Navarro adentra na produção fotográfica, a partir do laboratório, diferente de Geraldo de Barros.

\section{CONCLUSÃO}

A partir das discussões da última seção, percebe-se que através do estudo de caso comparado entre as obras selecionadas de Geraldo de Barros e Carlos Navarro há diálogos estéticos que estão articulados apesar das diferenças de contexto dos fotógrafos. A partir da relação dos elementos presentes nas imagens, associados às interpretações, foram observados pontos convergentes e divergentes entre as obras de cada um, relacionados à estética, técnica, controle, o conceito de "erro" e recepção da obra.

Também verificou-se que os artistas estudados contribuíram cada um a seu modo, com a subversão do código fotográfico, ao atravessarem os paradigmas dentro do contexto em que suas produções se desenvolveram.

Observou-se que a experimentação ainda é pouco explorada no ambiente fotoclubista em Manaus, parecendo não interessar tanto aos integrantes esse viés. Quanto à recepção desses trabalhos experimentais, entende-se que existe a flexibilidade no discurso institucional por parte da CONFOTO ao incentivar a liberdade processual 
dos membros. Contudo, percebe-se que a perfeição técnica é primordial na validação da imagem, mantendo alguns resquícios da época de Geraldo de Barros. Isso demonstra que os clubistas permanecem arraigados à tradição, evitando expandir-se para além do lugar-comum.

Observou-se também a ressonância da modernidade na obra de Carlos Navarro, afirmando sua singularidade no ambiente clubista e possibilitando a reflexão sobre o tema exposto em âmbito local. Por fim, salienta-se a importância de mais estudos em torno das produções fotoclubistas em Manaus, a fim de suscitar outras investigações nesse campo.

\section{Referências Bibliográficas}

COCCHIARALE, F. Videoarte no Brasil. In GURAN, M. (mediador). [versão para o inglês Eric Lethbrige]. Foto + vídeo+ arte contemporânea. - Rio de Janeiro: Aeroplano, 2010. Il. Color. - (arte \& tecnologia).p.22.

CONFOTO. XXVIII Bienal de arte fotográfica brasileira em preto e branco. Disponível em: < http://confoto.art.br/fotografia/xxviii-bienal-de-arte-fotografica-brasileira -em-preto-e-branco.html > Acesso em: 05 jul. 2015a.

CONFOTO. XXVIII Bienal de arte fotográfica brasileira em preto e branco. Disponível em: <http://confoto.art.br/fotografia/xxviii-bienal-de-arte-fotografica-brasileira-em -preto-e-branco/150-liberdade-de-criacao.html > Acesso em: 05 jul. 2015b.

COSTA, H. e SILVA, R. R. da. A fotografia moderna no Brasil: Helouise Costa, Renato Rodrigues da Silva. São Paulo: Cosac Naify, 2004.

DIEGUES, I. ORTEGAS, E. (org.). Fotografia na arte brasileira séc.XXI / organização Isabel Diegues, Eduardo Ortegas; colaboração Thyago Nogueira, Eduardo Brandrão, Ricardo Sardenberg; [tradução Alberto Dwek, Carolina Alfaro de Carvalho; textos de Janaína Melo, Ricardo Sardenberg]. Rio de Janeiro: Cobojó, 2013.

ENTLER, R. Fotografia contemporânea entre olhares diretos e pensamentos obtusos. Revista da Faculdade de comunicação e marketing da FAAP, São Paulo, n. 23, p. 62 -75. 1ㅇs semestre. 2011.

FAVRE, M. Cronologia. In: FERNANDES JUNIOR, R. (Org.). Sobras: Geraldo de Barros. São Paulo: Cosac Naify, 2006.p.162-174.

FOLHA ONLINE. Obra de russo seduz até a Disney. Disponível em: <http://musicaclassica.folha.com.br/cds/19/biografia.html>. Acesso em: 20 jun. 2015a.

FOLHA ONLINE. Igor Stravinsky: contexto histórico. Disponível em: <http://musica- 
classica.folha.com.br/cds/19/contexto.html>. Acesso em: 20 jun. 2015b.

FONTCUBERTA, J. O beijo de Judas. Fotografia e verdade. Tradução Maria Alzira Brum Lemos. Barcelona: Editorial Gustavo Gili, 2010.

BARROS, Geraldo de. Fotoformas. 2.ed. São Paulo: Cosac Naify, 2006.

KOSSOY, B. Fotografia \& história. 2. ed.rev. São Paulo: Ateliê Editorial, 2001.

Os tempos da Fotografia: o efêmero e o perpétuo. 3. ed. Cotia, SP: Ateliê Editorial. 2014.

LIMA, H. E. R. Fotoformas: A máquina lúdica de Geraldo de Barros. 2006.159f. Dissertação (Mestrado em Artes) - Escola de Comunicação e Artes da Universidade de São Paulo, São Paulo. Disponível em: <http://www.teses.usp.br/teses/disponiveis/27/27131/tde-13082009-154838/pt-br.php >. Acesso em: 01 maio. 2015.

MEIRA, B. Modernismo no Brasil: Panorama das artes visuais. São Paulo: Ática, 2006. Moderna para Sempre. Produção audiovisual: Caroline Rodrigues; Vídeo: Alícia Peres Fotografia; Edição: Karina Fogaça. São Paulo: Itaú Cultural, 2014. (11 min. 11 seg.) som., color. Port. Disponível em: < https://www.youtube.com/watch?v=PyW9s50SoEo >. Acesso em: 20 abr 2014.

Moderna para Sempre. Produção audiovisual: Caroline Rodrigues; Vídeo: Alícia Peres Fotografia; Edição: Karina Fogaça. São Paulo: Itaú Cultural, 2014. (14 min. 9 seg.) som., color. Port. Disponível em: < https://www.youtube.com/watch?v=e0lwWkvM8Sw >. Acesso em: 20 abr. 2015

NAKAGAMA, R. O retrato e a fotografia. In: SANTOS, J. Interior profundo - Mestre Júlio Santos, fotopintura = The deep within - Mestre Júlio Santos, photo painting/ Júlio Santos - Fortaleza, CE: Tempo D'Imagem, 2012.p.15-17.

NAVARRO, C. A. I. Depoimento manuscrito de Carlos Navarro. Manaus, 14 maio. 2015a. (Depoimento concedido ao autor)

NAVARRO, C. A. I. Processo Criativo. Manaus, 14 maio. 2015b. Registro para pesquisa: Fotografia e processos criativos: expressividade e memória na produção fotoclubista em Manaus. Entrevista concedida ao autor.

PRÄKEL, D; [tradução: Marina Belloli, Ronald Saraiva de Menezes]; [revisão técnica: Rodolpho Pajuaba]. Composição. 2. Ed. Porto Alegre: Bookman, 2013.

SANTANA, A. L. A Sagração da Primavera. Infoescola. Disponível em: <http://www. infoescola.com/musica/a-sagracao-da-primavera/>. Acesso em: 21 jun. 2015. 


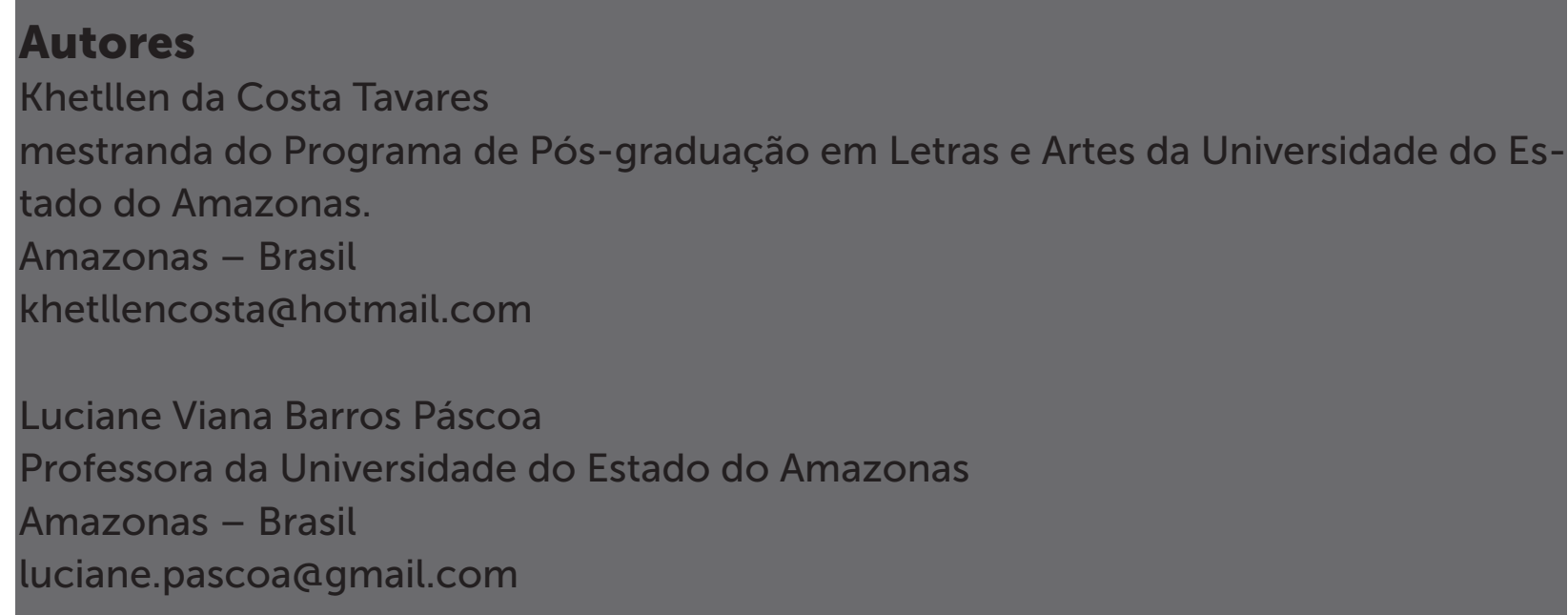

